\title{
COMPLICATED COURSE OF LATE PATIENT'S SURVIVAL AFTER THE CLASSIC BENTALL PROCEDURE WITH THE CABROL SHUNT
}

\author{
Aleksejus Zorinas ${ }^{1}$, Donatas Austys ${ }^{2}$, Vilius Janušauskas ${ }^{1}$, Ignas Rakita ${ }^{1}$, Rimantas Karalius ${ }^{1}$, \\ Robertas Stasys Samalavičius s ${ }^{3}$, Rimantas Stukas ${ }^{2}$, Kęstutis Ručinskas ${ }^{1}$ \\ ${ }^{I}$ Clinic of Cardiac and Vascular Diseases, Institute of Clinical Medicine, Faculty of Medicine, \\ Vilnius University, Lithuania, ${ }^{2}$ Department of Public Health, Institute of Health Sciences, Faculty of \\ Medicine, Vilnius University, Lithuania, ${ }^{3}$ Centre of Anaesthesiology, Intensive Therapy and \\ Pain Management, Vilnius University Hospital Santaros Klinikos, Lithuania
}

Keywords: pseudoaneurysm, anastomotic disruption, Bentall procedure, Cabrol shunt, heart failure.

\begin{abstract}
Summary
In the setting of bleeding into the perigraft space, the classic Bentall operation can be modified by the usage of the Cabrol shunt. This shunt is applied in order to drain the blood into the right atrium and it is expected to close gradually. Anastomotic suture line disruption along with concomitant blood flow into the perigraft space may rarely open the shunt and cause the right heart failure. Due to the anastomotic complications, the classic Bentall operation no longer is widely used in clinical practice, but patients who underwent such procedure some decades ago may be coping with various symptoms nowadays. In this article, the cases of anastomotic disruption as well as pseudoaneurysm formation and the opening of the Cabrol shunt 21 years after such kind of operation are presented. The patient underwent surgical repair and was confronted with the reoccurrence of the coronary pseudoaneurysm three years later.
\end{abstract}

\section{Introduction}

One of the surgical options for the aortic root replacement is the classic Bentall operation. In the setting of bleeding into the perigraft space, the Cabrol shunt can be employed for a bailout procedure [1]. Complications associated with a persistent blood flow within the perigraft space and the functional Cabrol shunt include congestive right heart failure, haemolysis, anaemia, compression as well as dehiscence of aortocoronary anastomoses, and pseudoaneurysm formation $[1,2]$.

The aim of the article is to present a complicated course of the late survival after the Bentall operation in which the Cabrol shunt is used.

\section{Case report}

A male whose age is 56 years had a Type A dissection complicated by a severe aortic regurgitation 21 years ago. Then, a classic Bentall operation with the usage of Cabrol shunt was performed. The patient remained asymptomatic for 10 years, but throughout this period he developed a chest pain and shortness of breath on moderate exertion. Consequently, disruption of the distal anastomosis along with a persistent blood flow into the perigraft space was diagnosed. The symptoms were mild and the patient was managed medically with a regular follow-up of computerized tomography (CT) imaging. Over a period of five years prior to his admission to the hospital, the diameter of the native ascending aorta increased from $74 \mathrm{~mm}$ to $98 \mathrm{~mm}$. As the symptoms were not limiting his social activity, he refused the surgery until the occurrence of severe peripheral edema, general weakness, and shortness of breath on a slight physical exertion.

Echocardiography showed a massive aneurysm of the ascending aorta. Disruption of the aortic graft at the distal anastomosis was noted. The Cabrol shunt along with a significant blood flow disruption was observed at that point. The ejection fraction of the right ventricle was moderate. The right atrium was significantly enlarged. The mechanical prosthesis of the aortic valve was functioning well.

CT showed that the size of the native ascending aorta has been $10.4 \mathrm{~cm}$. The diameter of the Cabrol shunt has been $7.5 \mathrm{~mm}$. Complete separation of an aortic intima starting at the disrupted suture line down to the level of bifurcation was noticed.

A redo surgery was performed. Complete disruption of the distal aortic anastomosis and partial dehiscence of the 
coronary anastomoses were found. The coronary suture lines attached to the graft were repaired. A distal aortic anastomosis was performed de novo and the functional Cabrol shunt was closed. The severely calcified and thickened native ascending aorta was left in situ.

The patient survived two resternotomies for bleeding, perforation of the diverticulum followed by laparotomy and the deep sternal wound infection. Following the extensive in-hospital rehabilitation program he was discharged on the 182nd day after the surgery.

The annual follow-up along with CT scans were performed for the patient; he had no heart failure symptoms. Thirty-six months after the surgery significant blood flow through the defect of the upper portion of the left coronary anastomosis and an increase of the perigraft space diameter were detected (Figure 1). Due to the high risk of mortality and morbidity of conventional redo surgery, percutaneous defect closure is being considered. The current patient's level of physical activity is very low, limited to necessary walks inside the apartment.
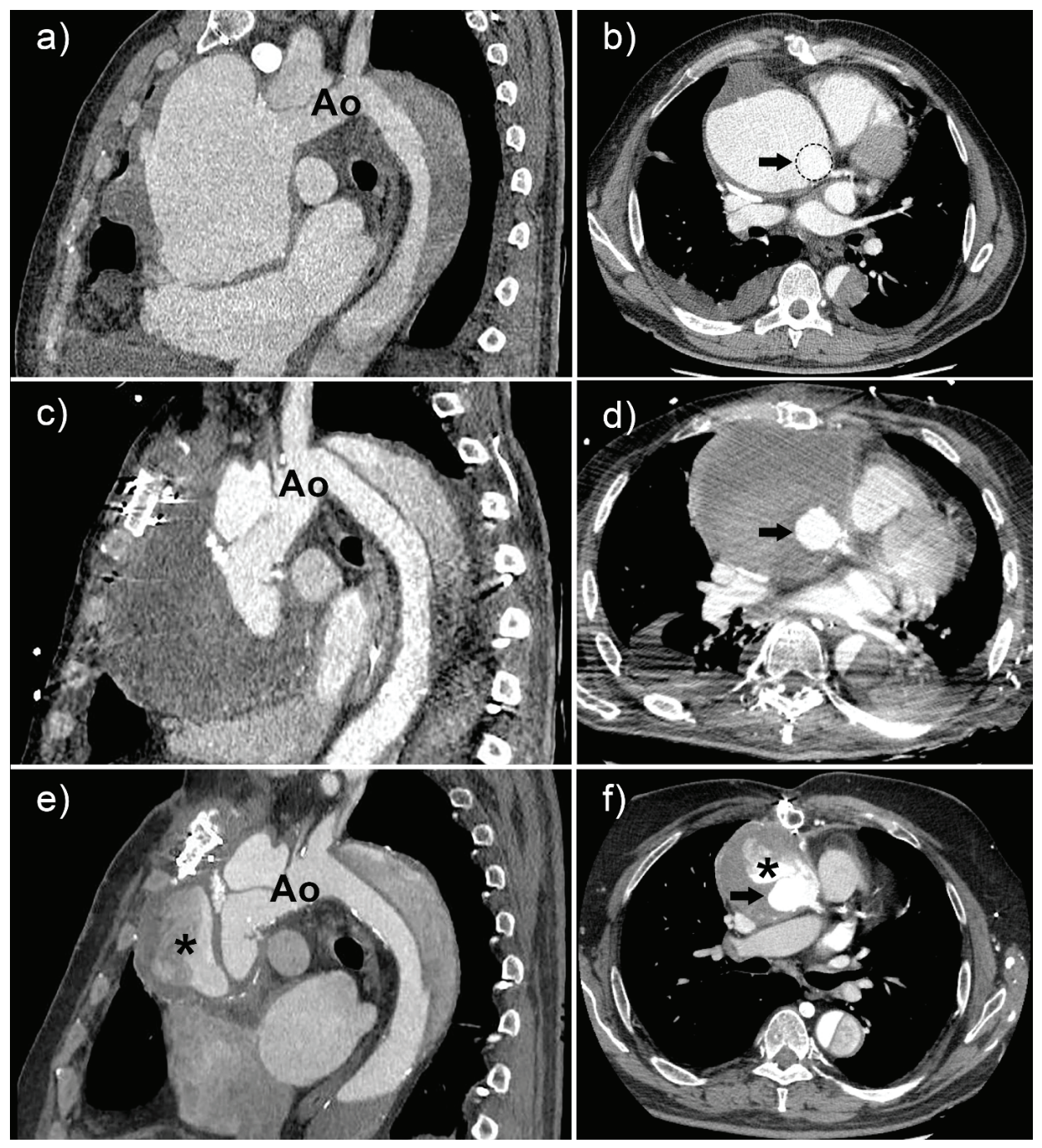

Figure 1. Contrast enhanced longitudinal reconstructions (a, c, e) and transverse CT images (b, d, f) of the chest: a), b) - before the reoperation, c), d) - one year after the reoperation, e), f) - three years after the reoperation.

\section{Discussion}

The classic Bentall operation had been widely used in the past, but later studies showed better short- and long-term outcomes of the open technique [3]. Nevertheless, due to a shorter time such kind of surgery can be reserved for the frail patients and elderly people whose dissection is limited to the ascending aorta [4].

One of the difficulties which surgeons encounter during the classic Bentall operation is technical completion of anastomoses which can result in their incompetence and cause a continuous blood flow into the perigraft space. It generates tension and can disrupt anastomoses $[5,6]$. In a setting of bleeding into the perigraft space, $\mathrm{Ca}$ brol offered to use a shunt in order to drain blood into the right atrium. Due to thrombosis the shunt is meant to close gradually. The case described in this article demonstrates that the shunt attached to the right atrium may open and cause the symptoms of heart failure decades after the operation. According to literature, spontaneous opening of the Cabrol shunt is particularly unusual and very few cases of this occurrence were reported in the past three decades $[7,8]$. Also, this case shows that even mild blood flow into the perigraft space may continuously increase the diameter of the native ascending aorta and subsequently disrupt anastomoses.

During a redo surgery the repair technique for coronary anastomosis has been chosen. 
Unfortunately, three years after the operation a defect of the left coronary anastomotic site along with the current pseudoaneurysm was diagnosed. Continuous shear stress in the thick, inelastic and severely calcified aorta could be the main cause of the suture line disruption along with the following leakage into the mediastinal space. Mediastinitis and the surgical technique also could have contributed to this process. Currently, thick adhesions within the native aorta confine pseudoaneurysm. If untreated, it can result in subcutaneous propagation of the pseudoaneurysm through the intercostal spaces or strangulation of the coronary artery causing myocardial infarction $[9,10]$. The authors of this article believe that in order to avoid this potential complication in redo surgery, the coronary anastomosis interposition graft technique should have been applied as it have been offered by Cabrol [11] and advocated by Okamoto [12].

\section{Conclusions}

Over the years, continuous blood flow into the perigraft space may cause gradual enlargement of the native ascending aorta and disrupt anastomoses without significant symptoms. Subsequent opening of the Cabrol shunt may lead to a heart failure. The case presented in this article demonstrates that in redo surgery, direct reattachment of the disrupted coronary anastomoses along with the native aortic wall should be avoided.

\section{Acknowledgments}

The authors of this article would like to express their gratitude to Dr. Palmyra Seménienè and Dr. Karolina Lušaitė for the medical management and imaging of the patient.

\section{References}

1. Svensson LG, Crawford ES, Hess KR, Coselli JS, Safi HJ. Composite valve graft replacement of the proximal aorta: comparison of techniques in 348 patients. Ann Thorac Surg 1992;54(3):427-437. https://doi.org/10.1016/0003-4975(92)90432-4

2. Gelsomino S, Morocutti G, Frassani R, Masullo G, Da Col P, Spedicato L. et al. Long-term results of Bentall composite aortic root replacement for ascending aortic aneurysms and dissections. Chest 2003;124(3):984-988.

https://doi.org/10.1378/chest.124.3.984

3. Kouchoukos NT, Wareing TH, Murphy SF, Perrillo JB. Sixteenyear experience with aortic root replacement. Results of 172 operations. Ann Surg 1991;214(3):308-318. https://doi.org/10.1097/00000658-199109000-00013

4. Malvindi PG, Modi A, Miskolczi S, Kaarne M, Velissaris T, Barlow C, et al. Open and closed distal anastomosis for acute type A aortic dissection repair. Interact CardioVasc Thorac Surg 2016. Available from: http://dx.doi.org/10.1093/icvts/ivw044. https://doi.org/10.1093/icvts/ivw044

5. Aomi S, Hashimoto A, Koyanagi H. Surgical treatment of false aneurysms following Bentall's operation. Japanese Annals of Thoracic Surgery 1994;14(6):467-470.
6. Imamaki M, Hashimoto A, Aomi S, Takazawa A, Nonoyama M, Hirai M, et al. A case report of a successful redo Bentall operation. Japanese journal of thoracic surgery 1996;49(6):502-504.

7. Sakano Y, Misawa Y, Kaminishi YI, Fuse K. Aorto-right atrium fistula caused by detachment after Bentall's operation: report of a case. Surg Today 2007;37(3):234-236.

https://doi.org/10.1007/s00595-006-3355-x

8. Yang WJ, Duan QJ, Cheng HF, Dong AQ. A case study of pulmonary embolism from the right atrial shunt after acute Type A aortic dissection surgery. Journal of Cardiothoracic Surgery 2014;9(1):180. https://doi.org/10.1186/s13019-014-0180-y

9. Morissette M, Lemire J, Poirier N, Bettez P. False aneurysm of the ascending aorta presenting as an acute myocardial infarction. Chest 1981;79:591-592. https://doi.org/10.1378/chest.79.5.591

10. Smetana M, Pirk J, Kacer P, Szarszoi O. Pulsatile pseudoaneurysm following a Bentall procedure. J Card Surg 2011;26(6):641-642. https://doi.org/10.1111/j.1540-8191.2011.01329.x

11. Cabrol C, Pavie A, Mesnildrey P, Gandjbakhch I, Laughlin L, Bors $\mathrm{V}$, et al. Long-term results with total replacement of the ascending aorta and reimplantation of the coronary arterines: J Thorac Cardiovasc Surg 1986;91(1):17-25.

https://doi.org/10.1016/S0022-5223(19)38476-4

12. Okamoto K, Casselman FP, De Geest R. Giant left coronary ostial aneurysm after modified Bentall procedure in a Marfan patient. Interact CardioVasc Thorac Surg 2008;7(6):1164-1166. https://doi.org/10.1510/icvts.2008.183103

\section{NEIPRASTA KOMPLIKACIJA VE்LYVUOJU LAIKO- TARPIU PO İPRASTINĖS KYLANČIOSIOS AORTOS PROTEZAVIMO SU KABROLIO JUNGTIMI OPERACIJOS}

A. Zorinas, D. Austys, V. Janušauskas, I. Rakita, R. Karalius, R. S. Samalavičius, R. Stukas, K. Ručinskas

Raktažodžiai: pseudoaneurizma, siuvimo jungties ịplyšimas, kylančiosios aortos protezavimas, Kabrolio jungtis, širdies nepakankamumas.

Santrauka

Kabrolio jungties suformavimas yra chirurginè metodika, taikoma, kai pacientui nustatomas kraujavimas ị periprotezinę ertmę po kylančiosios aortos protezavimo. Jungtis naudojama kraujui nutekèti iš aplink protezą esančios ertmès ị dešinijji prieširdị. Dažniausiai ši jungtis ilgainiui užanka. Retais atvejais protezo ir aortos siuvimo jungtis ịplyšta, kas nulemia kraujo patekimą ị periprotezinę ertmę. Tada Kabrolio jungtis gali atsiverti ir sukelti dešiniosios širdies pusès nepakankamumą. Dèl šios galimos komplikacijos aprašytoji operavimo metodika ịprastoje klinikinejje praktikoje nebetaikoma, tačiau ir dabar pasitaiko atvejų, kai prieš dešimtmečius operuoti pacientai kreipiasi ị medikus dèl minètos komplikacijos. Šiame straipsnyje aprašoma sudètinga klinikinė paciento ligos eiga dèl atsivėrusios Kabrolio jungties praejus 21 metams po kylančiosios aortos protezavimo.

Adresas susirašinèti: aleksejus.zorinas@santa.lt

Gauta 2019-11-15 